DOI: $10.17516 / 1997-1370-0774$

УДК 67

\title{
Awareness and Attitude of Latvian Construction Companies Towards Sustainability and Waste Recycling
}

\author{
Tatjana Tambovceva*a, Diana Bajare ${ }^{a}$, \\ Maria V. Tereshina ${ }^{b}$, Jelena Titkoc \\ and Irina Shvetsova ${ }^{a}$ \\ ${ }^{a}$ Riga Technical University \\ Riga, Latvia \\ ${ }^{b}$ Kuban State University \\ Krasnodar, Russian Federation \\ ${ }^{c}$ EKA University of Applied Sciences \\ Riga, Latvia
}

Received 24.05.2021, received in revised form 14.06.2021, accepted 01.07.2021

\begin{abstract}
Construction and Demolition Waste (CDW) creates the largest waste stream in the European Union. They consist of a heterogeneous mix of different components and constitute large amounts of waste which are often hazardous. Although some CDW is sent for recycling after the stripping and the demolishing of the building, a bigger share of the recovered CDW is restricted to low-value applications. It is widely accepted that reliable strategies and innovative technologies need to be developed to increase the share of CDW-derived materials in new residential constructions while simultaneously minimizing future CDW. Moreover, awareness and understanding the high value of CDW derived materials should be reached to improve building energy efficiency. The aim of the research is to evaluate the level of awareness and attitude towards CDW among Latvian construction companies. It was found out that Latvian construction business community has a positive attitude to waste management activities, and understands its importance in sustainable development.
\end{abstract}

Keywords: construction and demolition waste (CDW), awareness, recycling, sustainable development

This research was funded by the FLPP (Fundamental and Applied Research Projects) Programme in Latvia under the research project LZP-2020/1-0010 «Reuse of gypsum and expanded polymers from construction and demolition waste for acoustic and thermal insulation panels».

(C) Siberian Federal University. All rights reserved

* Corresponding author E-mail address: tatjana.tambovceva@rtu.lv ORCID: 0000-0002-9516-1530 (Tambovceva); 0000-0001-8982-5831 (Tereshina); 0000-0002-3250-5594 (Bajare); 00000003-1333-0941 (Titko) 
Research area: economics and national economy management (economics of environmental management).

Citation: Tambovceva, T., Bajare, D., Tereshina, M.V., Titko, J., Shvetsova, I. (2021). Awareness and attitude of Latvian construction companies towards sustainability and waste recycling. J. Sib. Fed. Univ. Humanit. Soc. Sci., 14(7), 942-955. DOI: 10.17516/1997-1370-0774.

\title{
Осведомленность и отношение латвийских строительных компаний к устойчивому развитию и переработке отходов
}

\author{
Т. Тамбовцева а, Д. Баяреа, \\ М.В.Терешина ${ }^{6}$, Е. Титко ${ }^{\mathrm{B}}$ И. Швецова \\ аРижский технический университет \\ Латвия, Рига \\ ${ }^{\sigma}$ Кубанский государственный университет \\ Российская Федерация, Краснодар \\ ${ }^{6}$ Высшая школа экономики и культуры \\ Латвия, Рига
}

\begin{abstract}
Аннотация. Отходы строительства и сноса (OCC) создают самый большой поток отходов в Европейском Союзе. Они состоят из неоднородной смеси различных компонентов и представляют собой большое количество отходов, которые часто несут в себе опасность. Хотя некоторая часть ОСС и отправляется на переработку после разборки и сноса здания, большая часть полученных ОСС ограничивается малоценным применением. Необходимо разработать надежные стратегии и инновационные технологии для увеличения доли материалов, полученных из ОСС при строительстве новых жилых зданий, одновременно минимизируя будущие ОСС. Более того, для повышения энергоэффективности зданий необходимо достичь осведомленности и понимания высокой ценности материалов, полученных из ОСС. Цель исследования оценить уровень осведомленности и отношения к ОСС среди строительных компаний в Латвии. Было установлено, что Латвийское строительное бизнес-сообщество положительно относится к деятельности по обращению с отходами и понимает ее важность для устойчивого развития.
\end{abstract}

Ключевые слова: отходы строительства и сноса, осведомленность, переработка, устойчивое развитие.

Это исследование финансировалось программой FLPP (Проекты фундаментальных и прикладных исследований) в Латвии в рамках исследовательского проекта LZP-2020 / 1-0010 «Повторное использование гипса и вспененных полимеров из отходов строительства и сноса для производства акустических и теплоизоляционных панелей».

Научная специальность: 08.00.05 - экономика и управление народным хозяйством (экономика природопользования). 


\section{Literature review}

\subsection{CDW in Europe}

Construction and demolition waste (CDW) is the material left from construction, refurbishment, road, and building demolition. CDW is compiled of a mix of different materials including inert waste, non-inert non-hazardous waste, and hazardous waste.

Since the CDW activities are vastly diversified they face many challenges that cause various related management practices being emerged. There are two main sectors impacting CDW are public works that also include road construction and the building sector. Despite the fact that recycled aggregates are widely used across the public works, due to the diversity of involved material the building sector still struggles to implement recycling activities for CDW. The additional factor affecting it is the variety of construction and building sites in terms of material properties and man- aged quantities. In fact, waste generated in the building sector is compiled of a mix of waste, especially hazardous and finished work waste (Fig. 1).

According to the data (Yeheyis et al., 2013), the building industry takes advantage of $40 \%$ of the total extracted natural resources, and besides that $25 \%$ of the forest resources. It is noticeable that countries with the aboveaverage gross domestic product per capita tend to have a higher material footprint, in which construction takes $50 \%$ of the countries' material use.

In 2018 the share of CDW was $36.0 \%$ of the total debris generation in the EU, it is the largest share among other types of activities. However, 36 percent is an average among all EU members, the statistics reveals the share of CDW around $70 \%$ or more in the countries like that in some countries like Luxemburg, Austria, Netherlands, and France. Statistical

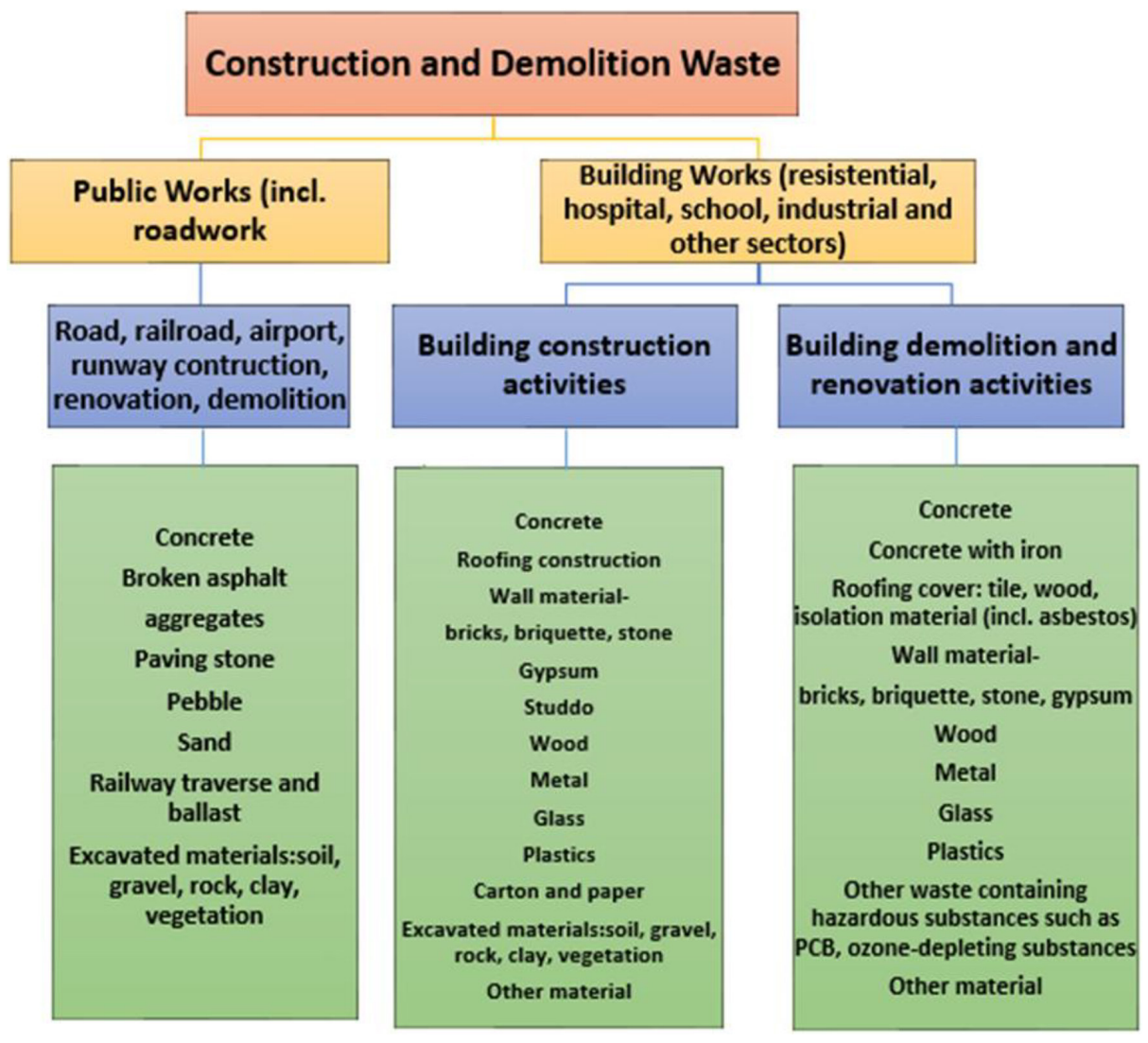

Fig. 1. Diversity of CDW per activities (Deloitte, 2017) 
data portrayed in Fig. 2 shows an indicative difference in the production of construction waste among the countries of the EU.

CDW makes up the most significant waste stream in the European Union. The total quantity of CDW included in the European statistical data is a sum of various waste categories generated within the Section F-construction sector. Over the previous decade, the construction sector of 28 European Union countries has been generating gradually rising quantities of CDW, which have a peak at around 850 million tons of waste in 2018 (Fig. 3).

As presented in the Figure $1 \mathrm{CDWs}$ consist of many different materials, such as bricks, gypsum, glass, solvents, plastic, wood, concrete, metals, excavated soil, and some hazardous substances, for instance, PCBs and asbestos. A large share of this waste can be recycled. The problem of a sustainable approach to CDW has become increasingly topical in the last years because its potential for boosting resource efficiency in the building sector is indisputable. It is clear today that such waste has a very high potential for recycling and reusing, due to the fact that some of its components are rich in resource value and can be successfully recycled. In fact, there is a demand for CDW-derived aggregates for drainage, roads, and many other construction projects. Nevertheless, only a small percentage of CDW is currently sent for recycling, most of it ends up in a landfill (Fig. 4). While in some European countries the share of recycled CDW reaches up to $95 \%$ many Member States hardly reach $10 \%$.

It is important for those Member States with law recovery rates to implement practices used in the success in the CDW recycling member states, however, identification and transfer of the good practices is not easy, since the CDW management varies notably across Europe. Besides, monitoring and data collection on the performance of CDW recycling practices is largely inaccurate because of issues with data traceability and availability. Moreover, the definition of CDW differs from state to state, which creates difficulties in cross-country comparison. For example, according to the Deloitte report (2017), the quality of CDW recycling data specifically on Latvia is very poor, therefore it is hard and practically of no use to analyze it.

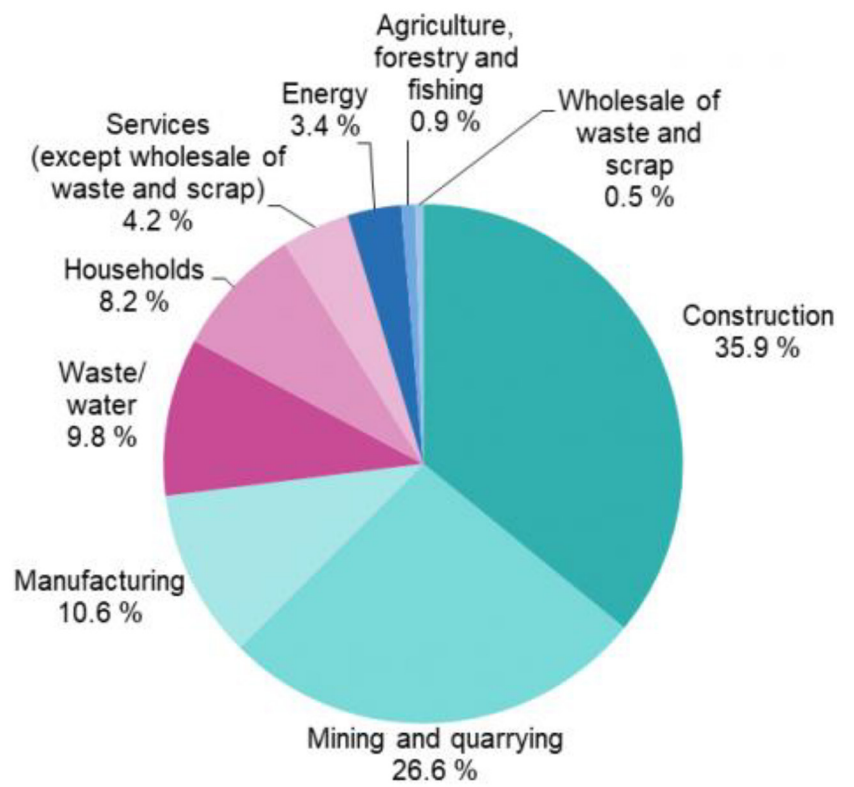

Source: Eurostat (online data code: env_wasgen)

Fig. 2. Waste generation by economic activities and households, EU, 2018

(\% share of total waste) (Eurostat, 2020a) 


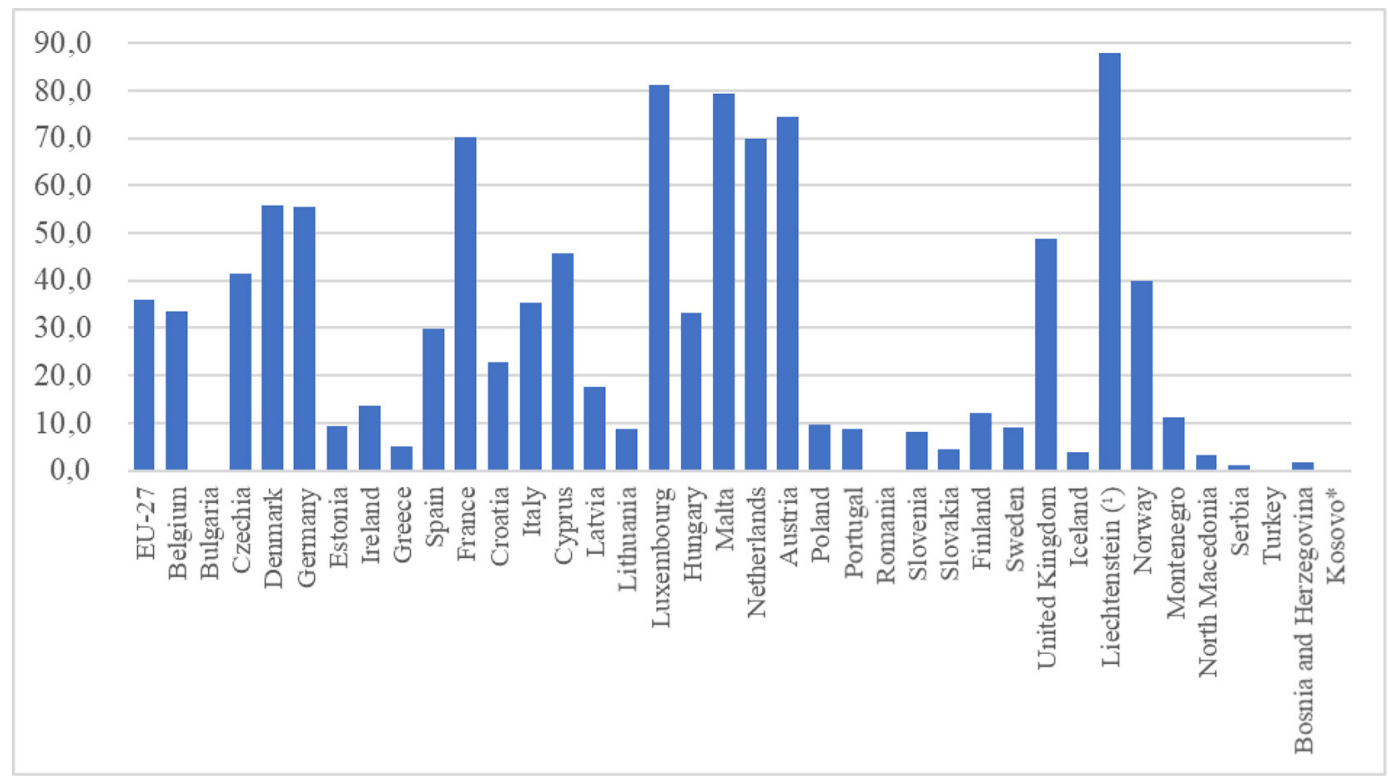

Fig. 3. CDW generated by the 28 EU member states in 2018

(\% share of total waste) (Eurostat, 2020b)

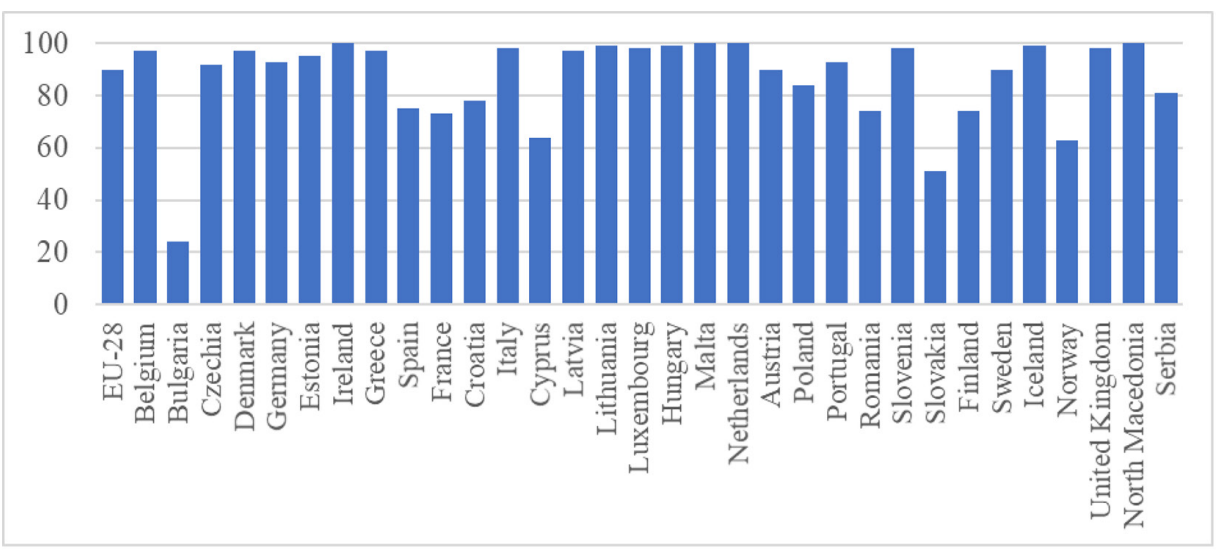

Fig. 4. Recovery rate of CDW in the 28 EU member states in 2018 (Eurostat, 2020c)

Research by Forsberg et al (2007) in the Netherlands showed that waste amounts on about $30-35 \%$ of the project's production cost, with an average waste volume per house of $6,860 \mathrm{~kg}$, $(4,480 \mathrm{~kg}$ of construction waste and $2380 \mathrm{~kg}$ of other solid waste). Among the reasons for the formation of such an amount of waste, the authors attribute both technical (low quality of materials (Bossink \& Brouwers, 1996; Lu et al, 2011; Nazech, Zaldi \& Trigunarsyah, 2008)), and organizational (mistakes of workers (Gavilan and Bernold, 1994)), also a low level of planning (Formoso et al., 2002) and weak motivation and awareness.

Worldwide accumulation of the $\mathrm{CW}$ in many countries taking the bulk percentage of the total waste generated. For example, in 2017 USA accumulated 569 million tons of CDW, whereas the production of municipal solid waste is half less than the amount (US Environmental Protection Agency, 2017). In Russia around 17 million tons of construction waste are gen- 
erated annually, more than $60 \%$ of which are brick and reinforced concrete waste (Oleynik, 2016). China alone generates approximately 1.5 billion tons of CDW year after year according to the AECOM report (Aecom, 2018).

There is undeniable evidence that waste generation is directly related to financial losses. For instance, the researchers (Forsberg \& Saukkoriipi, 2007) found out that in Sweden around $30-35 \%$ of the total construction project's cost was due to waste, in the United Kingdom material waste contributed an additional $15 \%$ of the total cost, around $11 \%$ expenditure overruns due to waste in Hong Kong, research is done in the Netherlands showed additional costs from $20 \%$ to $30 \%$ from material waste (Oko \& Emmanuel Itodo, 2013). Some estimations show that the amount of generated construction and demolition debris will only rise in the next years, reaching twice bigger the amount by the year 2025 (Transparency Market Research, 2020). This forecast can also be backed up with the projected growth of urbanization from $55 \%$ in 2018 up to $68 \%$ in 2050 , which in turn will lead to the rising demand for the development of infrastructures and civil construction volumes in the next decades (United Nations Department of Economic and Social Affairs, 2018).

\subsection{Awareness and attitude towards CDW management among construction businesses}

The attitude is defined as people's assessments of objects or circumstances that predispose them to act in a particular way (Rokeach $\&$ Sills, 1972). The functions of attitude and awareness are exceptionally important in the building industry, because the building industry and hence its workforce are commonly seen as having a very negative and inefficient environmental mindset (Teo \& Loosemore, 2001). These working cultures are primarily influenced by people's traditional educational backgrounds, which limit their access to knowledge about a specific topic. In the background of education and training for building professionals, environmental sensitivity was historically not taught. In recent times, though, this lack of environmental education was mitigated by the most influential modern force on environmen- tal views of people: the 'mass media' (Chan, 1998). While the building industry was a big generator of avoidable waste, it was reluctant to adopt environmentally sustainable practices. For past decade, landfills have served as a simple and cost-effective alternative to the city's inefficient activities. The climate, though, is changing. Resource scarcity, global warming, the emission levels, accelerating population growth, a more informed and proactive public, and an increasingly regulated corporate climate are putting pressure on the building sector to be more environmentally conscious (Teo \& Loosemore, 2001).

It must be specially emphasized that architects, as well as construction clients, engineers, and contractors who are directly involved in the project development phases as the main stakeholders, are equally responsible for managing and preventing CDW (Bao et al., 2019; Gamage et al., 2009; Häkkinen \& Belloni, 2011; Osmani et al., 2008). To augment their impact, designers, engineers, and managers need to recognize their responsibility, issues, and possibilities associated with waste aversion, and work on the viable methods by which significant enhancements can be accomplished.

However, Osmani et al. study (2008) reveals architects to be unenthusiastic to consider waste minimization as their responsibility routine, claiming that waste is occurred on the stage of on-site construction, specifically due to insufficient site planning, a misconception of drawings and inattention to the architectural requirements. Besides, respondents also mention that there are additional restrictions in allocating waste with the design stage such as the attitude of other stakeholders towards waste, customer's requirements, and most importantly ambiguities in the division of responsibilities and last-minute change due to customers' requirements. The author also ascertains that ecological safety is unfortunately not in the list of the main criteria of quality in building production.

Traditional construction focuses on cost, performance and quality objectives. Environmental awareness adds to these criteria the minimization of resource depletion, environmental degradation and the creation of a healthy built 
environment. At the 1st International Conference on Sustainable Building, held in 1994 in Florida, sustainable building was defined as «creating healthy built environments using resource efficient, environmentally sound principles» (Kibert, 1994). Begum et al. (2007) studied the economic feasibility of minimizing waste in a Malaysian construction project and concluded that adopting a minimization strategy such as recycling and reusing material could save $2.5 \%$ of the overall budget.

That is why many researchers associate CDW management among construction businesses with the philosophy and technologies of lean management; however, these are not identical concepts. The principles of sustainable construction include not only economic sustainability (increasing profitability through more efficient use of resources, including labor, materials, water and energy) and environmental sustainability (preventing harmful and potential irreversible impacts on the environment through the careful use of natural resources, minimizing waste, protection and, if possible, improvement of the environment), but also so- cial aspects, including responding to the needs of people at any stage of participation in the construction process (from commissioning to demolition), ensuring the involvement of the construction business in the implementation sustainable development goals, environmental awareness.

According to Abidin (2010) '...The pace of actions towards sustainable application depends on the awareness, knowledge as well as an understanding of the consequences of individual actions' (See Fig. 5).

Environmental awareness and attitude can be viewed as a new paradigm, where CDW management defines the framework for the design of buildings and the construction industry as a whole, as well as decision-making at all stages of the life cycle of a construction object.

Based on the observed studies it could be assumed that problems in mitigating construction waste may be due to attutial behaviour of professionals working in the construction industry, as well as unclearly defined responsibilities for reducing and preventing construction waste.

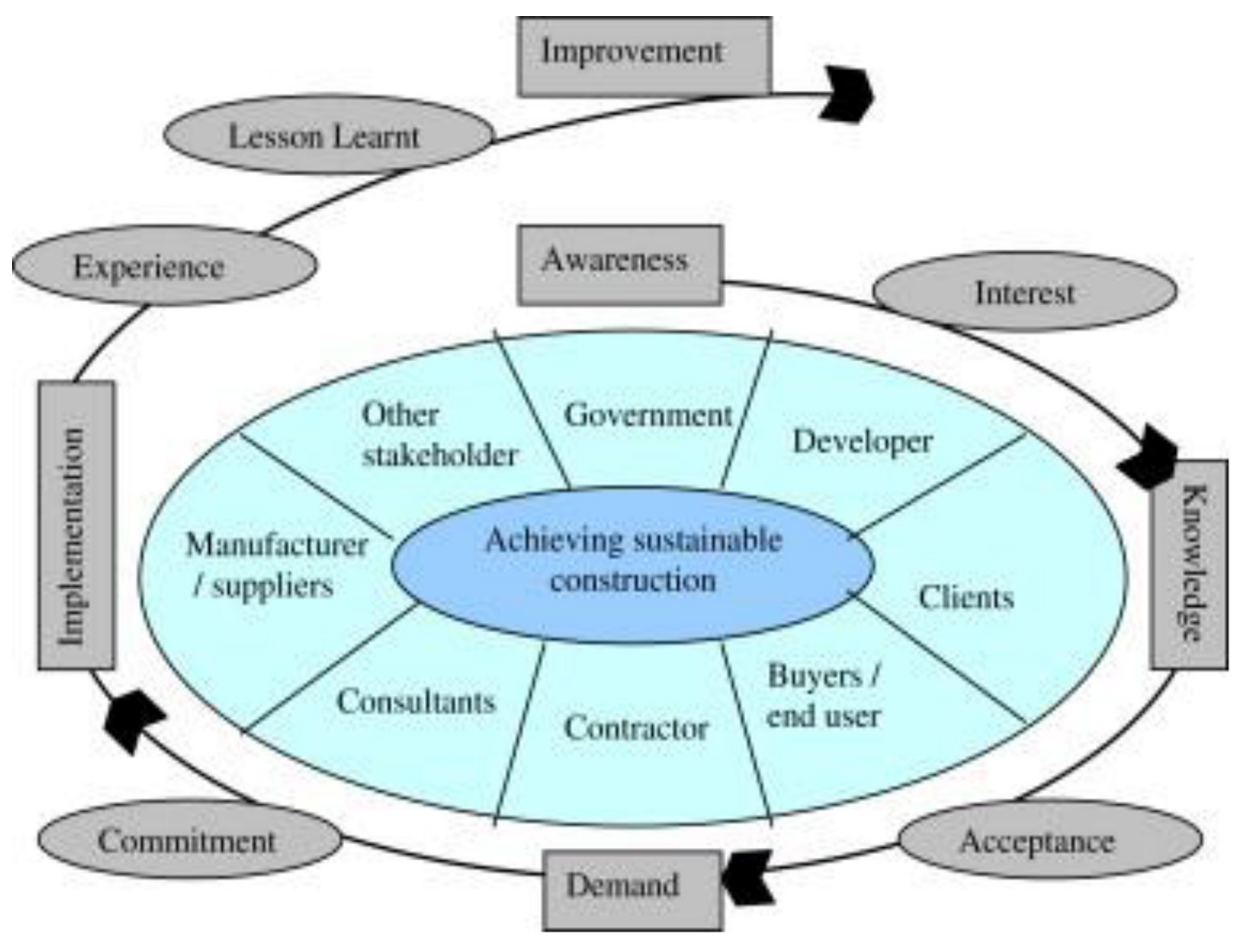

Fig. 5. The path for achieving sustainable construction (Abidin, 2010) 


\section{Methodology}

This research was conducted for the purpose of obtaining a deeper understanding of the attitudes and the present level of provision of education about construction waste management among the professionals involved in the industry. Owing to the current conditions resulted from the restrictions of interviewing face-to-face, as an alternative although the equally effective mechanism of primary data collection was chosen a questionnaire-based collection of data.

Firstly, an extensive analysis of the researches and publications focused on the background of construction waste management and its current and emerging trends has been done to: understand the present situation in the sphere of construction waste management, acquire a comprehension of the legislations on building debris in the EU and the attitude of specialists involved in the managing thereof. Secondly, the questionnaire for target group construction companies was designed after studying the precedent surveys conducted within a similar topic in other countries. The questionnaire was then addressed to be internally published to the members of the Latvian Civil Engineers Association. Where engineers, construction managers, and architects within the selected companies who directly or indirectly related to the management of the waste produced as the result of the construction or demolition work.

The questionnaire design is based on the analysis of similar studies conducted to evaluate the perception and/or existing situation in the construction waste industry. Some methods and focus points of the interviews were taken into account in the design of this questionnaire to meet the objectives of this research. For reliable data interpretation questions included in the questionnaire were multiple-choice, some of the answers were set in accordance with the Likert Scale from 1 to 5 . This is a psychometric scale that is often used in questionnaires and surveys. It most often assesses the degree of agreement or disagreement with each judgment (Table 1).

To receive reliable data, it was need to be found out:

- To what extend professionals are aware of the general situation on CW and related sustainability concepts;

- To what extend specialist engaged in the construction sphere are satisfied with the opportunities and conditions provided;

- Are professionals motivated and willing to implement sustainable approaches while managing $\mathrm{CW}$;

- What are the opportunities and obstacles in improving the management of construction-related waste.

Authors also assumed that neither of the answers might be a proper interpretation of the desired response, therefore most of the questions include an open answer or «other», which allowed people in the survey to specify their point of view.

Table 1. Structure of the questionnaire

\begin{tabular}{|c|c|c|}
\hline & Content of the question & Type of the question; evaluation scale \\
\hline Q_1 & Awareness about sustainable waste management & Closed; self-perception; 5 alternative responses \\
\hline Q_2 & $\begin{array}{c}\text { Main sources of information about } \\
\text { waste minimization procedures }\end{array}$ & Closed; 5 alternative responses \\
\hline Q_3 & Attitude to recycling & Closed; Likert-type 4-point scale \\
\hline Q_4 & $\begin{array}{c}\text { Reasons for engagement in waste } \\
\text { management initiatives }\end{array}$ & Closed; 4 alternative responses \\
\hline Q_5 & Intention to minimize produced waste & Closed; 9 alternative responses \\
\hline Q_6 & $\begin{array}{r}\text { Intention to implement green/ sus- } \\
\text { tainable technologies }\end{array}$ & Closed; 4 alternative responses \\
\hline Q_7 & Perceived responsibility &
\end{tabular}


There were also a few constraints of the research:

- The questionnaire was anonymous, therefore, the data collected could not be sorted by the type of profession (architects, engineers, managers, etc.) among the respondents. This fact makes this research limited to obtain an overall understanding of the construction sphere professionals' perception and therefore restrains to differentiate the result by the occupation.

- The research was limited to a questionnaire-based data collection only, without following face-to-face interviews due to the current pandemic situation.

- The geographical limitation is enclosed in targeting professionals involved in the related sphere in Latvia.

The questionnaire was disseminated to the members of the Latvian Civil Engineers Association (LBS). Where engineers, construction managers, and architects who directly or indirectly related to the management of the waste produced as the result of the construction or demolition work.

Causes of construction waste outputs are reflected in Fig. 6.

Four highest contributory factors to material waste at construction sites are revealed in the study presented in Fig. 6. These are Demolition works which were ranked having the greatest impact on material wastage, on- site works second-highest rank, which also matches with the previous results obtained for Question 8; Procurement of surplus/ wrong materials was chosen by $42 \%$ of the respondents; and Lack of construction waste management which has a comparatively high impact on wastage of construction materials according to the specialists. The remaining options have a moderate contribution to $\mathrm{CW}$ generation, ranging from $20 \%$ to $23 \%$ due to design changes and material damage respectively. Whereas respondents' opinion is that material wastage occurs less while restoration works and project closure. This is consistent with a previous study conducted by Oko and Emannuel Itodo (2013), which recognizes waste on-site works such as workmanship, storage facilities, and rework as having a substantial contribution to materials wastage. This finding demonstrates that all onsite participants, from the site manager to all construction workers, must undergo adequate training for material waste on-site.

\section{Results}

In total 198 responses were received; out of this number of answers, it is possible to obtain a reliable analysis. All of the responses were of sufficient quality with all questions answered (all questions were marked as obligatory). The interpretation of the results of each question presented below.

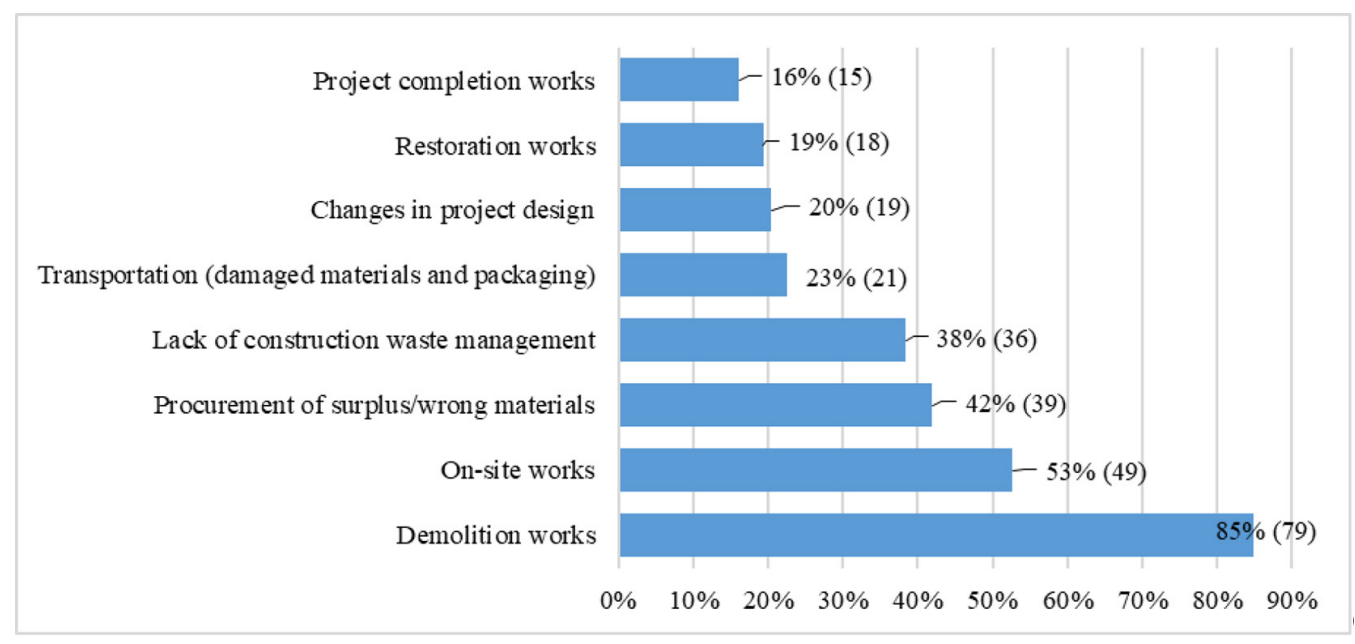

Fig. 6. Types of construction works contributing to material wastage (respondents' opinion) 
The data collected for the question 1 «Awareness about sustainable waste management» indicates that the majority of the respondents are either have vague knowledge and are not able to put this knowledge into practice $(38 \%)$ or have little experience, but still not confident in practicing those skills on their own $(33 \%)$. Whereas $17 \%$ of the respondents are capable of applying their knowledge independently, and only $4 \%$ out of all repliers can teach. This indicates they may doubt their own ability to efficiently handle the waste. Site managers may consider waste management to be a low priority, perhaps incompatible with other goals. They are usually under tremendous pressure to achieve other business objectives, such as expense, time, and quality. If this were the case, their confidence in waste management's return on effort would also be poor.

Results on the main information sources (Q2) used by responding parties are following. Having in mind that now information is easily accessible via internet sources, it was although important to know what the most convenient and preferred methods are of obtaining knowledge regarding $\mathrm{CW}$ minimization in Latvia. The prevailing number of practitioners prefer to rely on the experience of other construction companies, yet some of the respondents highlighted that mostly their preference is to rely on the experience of other EU countries (these responses were reduced to the answer «Experience of other construction companies» for convenient data management). The second most used source of information is knowledge accumulated within the various Latvian associations, like Latvian Civil Engineers Association, Latvian Union of Architects or any other. $22 \%$ of the respondents prefer to use a website of Latvian national database of standards (lvs. lv). The rest interviewed people choose either social media data $(16 \%)$ or local legislations (2\%), like those to guide them through the concepts of $\mathrm{CW}$ minimization.

To acquire a prevailing perception of the recycling of $\mathrm{CW}(\mathrm{Q} 3)$ the respondents were asked to show their attitude towards $\mathrm{CW}$ recycling on the Likert scale ranging from Not Important to Very important. The majority of the responses portray that most of the pro- fessionals are concerned about how the waste resulted from their construction projects is recycled. By the majority here can be assumed a $39 \%$ who find it Important, whereas 26 and 25 percent find recycling of CW Very and Moderately Important respectively. Overall, it can be clearly seen that professionals within Latvia are concerned about recycling construction and demolition waste. There are, however, $10 \%$ of those who find recycling of the CDW under their construction projects as not a significant issue they should care about. Studying previous survey cases researchers (Osmani, Glass and Price, 2008) found out the factors which influence unwillingness to take responsibility on proper $\mathrm{CW}$ management or incomprehension how to implement thereof. Besides, an overall positive response shows that specialists determine the recycling of CDW as Important, which sets a good note of awareness and consciousness about issues arising from CDW.

Question 4 about Reasons for engagement in waste management initiatives was targeting to understand the reasons for construction professionals (companies) to be concerned about $\mathrm{CW}$ production. Specifically, it helps to determine the reasons of the respondents for taking the responsibility to manage waste that arose from construction and demolition. This question also seeks to potentially determine the drivers and control the levellers of the respondents in implementing sustainable CW management. The results present that more than half of the replies are accounted for companies being concerned about the waste issue because they understand its negative impact on the environment. About a third of the respondents consider waste as a creator of additional expenses, which indeed is a good reason because as showing that $\mathrm{CW}$ in some countries can make up to $30 \%$ of the project expenses. Some specialists (10 percent) assume $\mathrm{CW}$ is not their concern, saying that it has to be a problem of the waste management companies. Other minorities representing $3 \%$ consider waste only because the government has put an obligation on them to control and properly manage their waste. Some people $(2 \%)$ have presented their options indicating the application of BREEAM certification and ISO 14001 standard, which 
also indicated their responsible approach which may be supported by either environmental or financial considerations.

Question 5: «Intention to minimize produced waste» asked about current/ potential conditions to implement waste minimization strategies in their companies. I other words, the answers were designed in such a way as to understand if the respondents are planning (or not planning) or already implemented CW minimization strategies and what are the reasons for implementing thereof. Besides, the authors also assumed an open answer, if none will be appropriate. Figure 7 summarizes the data collected for question 5; where about a third of responses are accounted for future implementation of sustainable methods of waste minimization.

About a quarter of the respondents are satisfied with the existing technologies they use. However, it is also interesting to notice, that those who appeared to be satisfied with their technologies also said to have a lack of knowledge about sustainable waste management technologies and are not able to practice. Therefore, it can be assumed that waste management technologies used in the corresponding companies are far from being called sustainable. Another correlation is noticed in the responses of those whose answer was «Yes, current governmental requirements are obliging us to», the prevailing majority showed their concern about $\mathrm{CW}$ due to an environmentally friendly attitude, which shows a conflicting relationship between questions 4 and 5. A more logical interrelation was noticed within those who showed their concern for either environmental or financial issues and consequently have implemented ISO 14001 standard (22\%). Another controversial replied was noticed, when the respondent claims to train young civil engineers on proper construction waste management, but at the same time saying that he/she «Knows something, no experience» in question 1 .

As one more question (Q6), the authors choose to study «Intention to implement green/ sustainable technologies», i. e., whether the cost obstacle is playing a vital role in preventing companies to put into practice any types of sustainable technologies resulting to cut material wastage. The results show, that almost half $(47 \%)$ of the participants would implement sustainable technologies in their construction. Understanding the environmental and economic benefits it may give in the long-run, even additional expenses are not the obstacle of implementing thereof. Another half

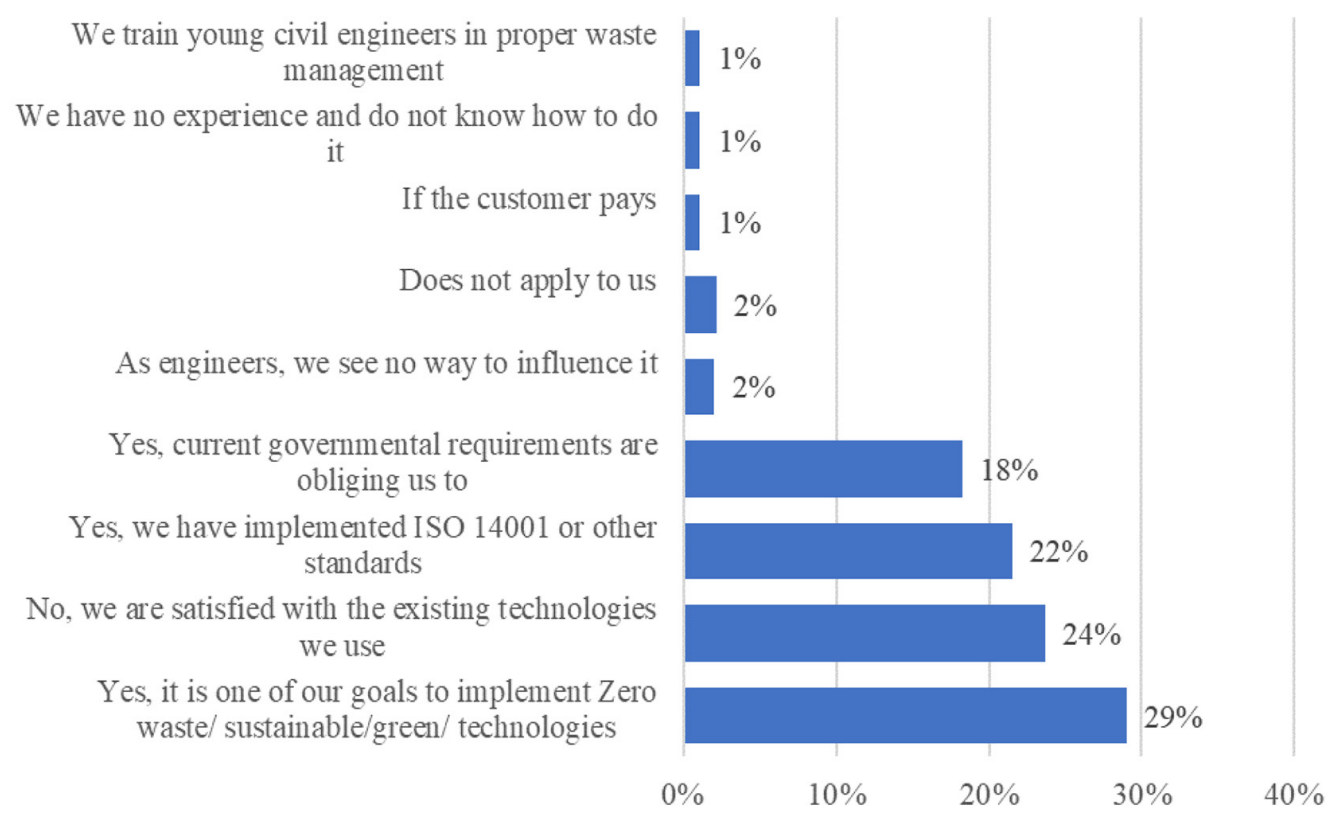

Fig. 7. Conditions for applying CW minimization methods (respondents' opinions) 
of the responses are almost equally distributed either to not change anything in their present methods $(29 \%)$ or change, but if it will only be required by the government $(24 \%)$. This result shows the consciousness and readiness for changes among those who are involved in the construction sphere, but perhaps, due to the obstacles identified in question 11, there is still not enough enabling environment in which sustainable waste management approached will flourish.

The question about Perceived responsibility (Q7) allowed people participating in the survey to choose multiple answers. Having in mind, that attitudes upon the responsibility will likely vary as per culture and waste management policies across multiple companies and throughout various professional groups within this research. It is still important to identify who is/ are the main responsible stakeholder(s) in the respondents' opinion. Similarly, as it was discovered by Osmani, Glass and Price (2008), the majority of respondents do not think that architects may anyhow be responsible for the CW minimization, where a prevailing combination of answers was: 1 . Construction company $(79.8 \%)$ or 2 . Waste management companies $(72.3 \%)$. The same two, but additionally emphasizing the responsibility of suppliers and contractors $(31.9 \%)$. About $22 \%$ of respondents believe that architects can influence a waste reduction in the design stage. The data obtained from this question may suggest es- tablishing some leading assertions about the next question which aims to reveal the opinion of the respondents on which stage most of the construction waste is generated.

\section{Conclusion}

This research focused on the current climate within construction waste management, what is the level of awareness and attitude towards CDW among Latvian construction companies. Since environmental conservation has been mainly critical worldwide, it is crucial to regulate the environmental impact caused by construction activities. By introducing reuse, recycle and reduce, material wastage in construction can be significantly mitigated. While the transition to a circular economy is currently at the forefront of Europe's policy agenda, Europe still has a linear model of goods and services being generated and used within the construction sphere. It was found out that Latvian construction business community has a positive attitude to waste management activities, understanding its importance in sustainable development. The main problem of addressing waste reduction lies in the different angles of perception of the value of each construction project stakeholder. Although waste is considered unavoidable and there is a lack of experience and expertise among the participants of the survey, they do show their environmental consciousness and willingness to adopt $3 \mathrm{R}$ principles.

\section{References}

Abidin, N.Z. (2010). Investigating the awareness and application of sustainable construction concept by Malaysian developers. In Habitat International, 34(4), 421-426. Available at: https:/doi.org/10.1016/j. habitatint.2009.11.011

Aecom (2018). People's Republic of China: Construction and Demolition Waste Management and Recycling Prepared by AECOM Asia Company Limited for the PRC Ministry of Housing and Urban-Rural Development and the Asian Development Bank.

Deloitte (2017). Resource Efficient Use of Mixed Wastes - Improving management of construction and demolition waste. Final report, Brussels, Belgium.

Bao, Z., Lu, W., Chi, B., Yuan, H., \& Hao, J. (2019). Procurement innovation for a circular economy of construction and demolition waste: Lessons learnt from Suzhou, China. In Waste Management, 99, 12-21. Available at: https://doi.org/10.1016/j.wasman.2019.08.031

Begum, R.A., Siwar, C., Pereira, J.J., and Jaafar, A.H. (2007). Factors and values of willingness to pay for improved construction waste management: A perspective of Malaysian contractors. In Journal of Waste Management, 27, 1902-1909. Available at: https://doi.org/10.1016/j.wasman.2006.08.013 
Bossink, A.G. and Brouwers, H.J.H. (1996). Construction waste: quantification and source evaluation. In Journal of Construction Engineering and Management, 122, 55-60. Available at: https://oi.org/10.1061/ (ASCE)0733-9364(1996)122:1(55)

Chan, K. (1998). Mass communication and pro environmental behaviour: Waste recycling in Hong Kong. In Journal of Environmental Management, 52(4), 317-325. Available at: https://doi.org/10.1006/ jema.1998.0189

Forsberg, A. \& Saukkoriipi, L. (2007). Measurement of waste and productivity in relation to lean thinking. In Proceedings IGLC. (Vol. 15). Michigan, USA.

Eurostat (2020a). Waste statistics Statistics Explained. Available at: https://ec.europa.eu/eurostat/ statistics-explained/index.php?title=Waste_statistics\#Waste_generation_excluding_major_mineral waste

Eurostat (2020b). Generation of waste by economic activity (Construction). Available at: https://ec.europa.eu/eurostat/statistics-explained/index.php?title=Waste_statistics\#Total_waste_generation

Eurostat (2020c). Recovery rate of construction and demolition waste. Available at: https://ec.europa. eu/eurostat/databrowser/view/cei_wm040/default/table?lang=en

Formoso, T.C., Soibelman, M.L., Cesare, D.C., and Isatto, E.L. (2002). Material waste in building industry: Main causes and prevention. In Journal of Construction Engineering and Management, 128, 316-325. Available at: https://doi.org/10.1061/(ASCE)0733-9364(2002)128:4(316)

Gamage, I.S.W., Osmani, M., \& Glass, J. (2009). An investigation into the impact of procurement systems on waste generation: The contractors' perspective. In Association of Researchers in Construction Management, ARCOM 2009 - Proceedings of the 25th Annual Conference, December 2014, 1031-1040.

Gavilan, R.M., and Bernold, L.E. (1994). Source Evaluation of solid waste in building construction. In Journal of Construction Engineering and Management, 120, 536-552. Available at: https://oi.org/10.1061/ (ASCE)0733-9364(1994)120:3(536)

Häkkinen, T., \& Belloni, K. (2011). Barriers and drivers for sustainable building. Building Research and Information, 39(3), 239-255. Available at: https://doi.org/10.1080/09613218.2011.561948

Kibert, C.J. (1994). Final Session. In First International Conference of CIB TG 16 on Sustainable Construction, Tampa, Florida.

Lu, W., Yuan, H., Li, J.J., Hao, J.L., Mi, X., Ding, Z. (2011). An empirical investigation of construction and demolition waste generation rates in Shenzhen city, South China. In Journal of Waste Management, 31, 680-687. Available at: https://doi.org/10.1016/j.wasman.2010.12.004

Nazech, E.M., Zaldi, D., and Trigunarsyah, B. (2008). Identification of construction waste in road and highway construction projects. In Proceedings of 11th East Asia-Pacific Conference on Engineering and Construction, Taiwan.

Oko, A., \& Emmanuel Itodo, D. (2013). Professionals' views of material wastage on construction sites and cost overruns. In Organization, Technology \& Management in Construction: An International Journal, 5(1), 747-757. Available at: https://doi.org/10.5592/otmcj.2013.1.11

Oleynik, S. (2016). Amounts and sources of construction and demolition waste. In Russian Journal of Resources, Conservation and Recycling, 3(1), 1-10. Available at: https://doi.org/10.15862/02rrol16

Osmani, M., Glass, J., \& Price, A.D.F. (2008). Architects' perspectives on construction waste reduction by design. In Waste Management, 28(7), 1147-1158. Available at: https:/doi.org/10.1016/j.wasman.2007.05.011

Rokeach, M., \& Sills, D.L. (1972). The nature of attitudes. In International Encyclopedia of the Social Sciences (pp. 449-570). Macmillan and The Free Press, New York.

Transparency Market Research (2020). Construction \& Demolition Waste Recycling Market - Global Industry Analysis and Forecast 2025. Available at: https://www.transparencymarketresearch.com/ construction-demolition-waste-recycling-market.html

Teo, M.M.M., \& Loosemore, M. (2001). A theory of waste behaviour in the construction industry. In Construction Management and Economics, 19(7), 741-751. Available at: https://doi. org/10.1080/01446190110067037 
United Nations Department of Economic and Social Affairs (2018). In World Urbanization Prospects The 2018 Revision.

US Environmental Protection Agency (2017). Sustainable Management of Construction and Demolition Materials. Available at: https://www.epa.gov/smm/sustainable-management-construction-anddemolition-materials

Yeheyis, M., Hewage, K., Alam, M.S., Eskicioglu, C., \& Sadiq, R. (2013). An overview of construction and demolition waste management in Canada: A lifecycle analysis approach to sustainability. In Clean Technologies and Environmental Policy, 15(1), 81-91. Available at: https://doi.org/10.1007/s10098-012-0481-6 